Јулијана Вулетић ${ }^{\mathbf{1}}$

Универзитет у Крагујевцу

Филолошко-уметнички факултет удк 811.163.41'282.4(430)

811.163.41:811.112.2

DOI 10.18485/zivjez.2016.36.1.4

Оригинални научни рад

\title{
ПРОЦЕС ЗАМЕНЕ СРПСКОГ ЈЕЗИКА НЕМАЧКИМ: ЈЕДНО ИСТРАЖИВАЬЕ
}

Циљ и задатак овог прилога јесте представљање резултата трогодишњег истраживања и анализе процеса замене језика у српској заједници у немачком граду Инголштату са кратким освртом на ток истраживања и појмовна одређења.

Кључне речи: контактна лингвистика, процес замене језика, феномени језичког контакта

\section{Увод}

Савремено друштво је вишејезично и више него икада обележено разноврсним језичким и културним контактима. Према узроцима се ови контакти могу поделити на вољне (миграције, увоз радне снаге, трговина, дипломатија, туризам, образовање) или невољне (колонизација, ратови, освајања територија, мењање граница). По својој природи они могу бити посредни (путем медија, филмова, превода и сл. у једнојезичним заједницама) и непосредни (миграторна кретања, двојезичне друштвене заједнице и сл.). Појаве, исходи и очекиване последице међусобних утицаја језика као социолигвистичког и лингвистичког феномена нису нов предмет изучавања. 0 њима се говори и оне се изучавају од Шухарта преко Вајнрајха до Клајна и Мајерс-Скотон до данашњих дана у контексту различитих типова контаката међу различитим језичким паровима. Српски језик у контакту са германским језицима највише је

$\overline{\text { julijanavuletic@yahoo.de }}$ 
истраживан у англофоним контекстима, док се мањи број радова бавио и контатком српског језика са немачким. Међутим, на основу доступне научне литературе може се констатовати да су међусобни утицаји српског и немачког језика истраживани превасходно на дијахроном плану у контексту посредних контаката (језичке посуђенице). Другим видом контаката, тачније непосредним језичким додирима и њиховим динамизмима, бавили су се малобројни аутори, и то до почетка 90-их година 20. века. Али, и овде смо, на основу прегледа научних радова који се баве изучавањем српског дијаспоралног језика у Немачкој, дошли до закључка да су ова истраживања спровођена пре свега у социолигнвистичком контексту са акцентом на двојезичност деце југословенских радника на привременом раду 70-их и 80-их година. Стање српског дијаспоралног језика у Немачкој са системсколингвистичког и социолингвистичког становишта са освртом на последице контакта српског језика са немачким језиком и исходе који остављају трага у процесу језичких промена и замене/очувања језика код различитих генерација миграната до сада готово и да није било предметом истраживања.

\section{1. Предмет, циљ и методе истраживања}

У овом раду желели бисмо да прикажемо резултате емпиријског истраживања процеса замене језика са пратећим феноменима структурних промена у српском језику у миграционом контексту од прве до треће генерације радних миграната. Посебан акценат стављен је на ванјезичке чиниоце у којима се у основи налази почетак и ток процеса замене језика. Наслањајући се на дефиницију да предмет истраживања контактне лингвистике представљају процеси иницирани и активирани сусретањем двају или више језика или језичких варијетета и њихових говорника, како на индивидуалном, тако и на друштвеном плану, предмет истраживања представљао је непосредни језички контакт српског и немачког језика на подручју Савезне Републике Немачке на примеру 27 породица са 
83 испитаника ентолингвистичке заједнице Срба у баварском граду Инголшату, које су обухватале групације испитаника од прве до треће генерације радних миграната².

Истраживање је имало за циљ да се у оквиру одређених теоријских постулата (Вајнрајх, Хауген, Клајн и др.) и на основу резултата емпиријских истраживања одговори на питања која се тичу фактора релевантних за процесе очувања или замене језика, утврђујући фазу процеса замене језика у којој се налази истраживана заједница. Поред тога, у раду смо понудили и објашњења језичких промена у српском језичком систему под утицајем система немачког језика и указали на правце евентуалних будућих истраживања. Јасно је да се овај пресек социолингвистичког и лингвистичког стања истраживане етнолингвистичке заједнице, као и резултати добијени истраживањем, односе на конкретну заједницу и конкретан корпус. Имајући у виду могуће различитости у погледу социодемографских и лингвистичких услова и околности у другим земљама пријема немачког говорног подручја, клонили смо се уопштавања. Ипак, добијени резултати засигурно омогућавају увид у опште тенденције развоја српског језика и у другим земљама пријема немачког говорног подручја, као и у тенденције кретања животног циклуса српско-немачких билингвалних заједница. На тим основама се предвиђају исходи у животном циклусу истраживане етнолингвистичке заједнице, а на темељу тога указујемо на могућности и потребе предузимања евентуалних институционализованих мера у циљу што дужег очувања српске говорне заједнице у немачкој дијаспори уопште.

Језичку ситуацију Срба у СРН, структуре и услове језичке продукције и рецепције истраживали смо у макросоциолинг-

2 У истраживани корпус су, међутим, незаобилазно ушли и они Срби и Српкиње који су женидбом/удајом за припаднике друге генерације дошли у Инголштат да живе и ту засновали своје породице, потом особе које су егзогамијом ушле у истраживани корпус, три породице чији се чланови могу сврстати у прву, другу и трећу генерацију миграната четвртог таласа миграција, као и једна породица са представницима четврте и пете генерације миграната првог таласа. 0 таласим миграција видети код Ивановић (2012) и Павлица (2005). 
вистичком контексту полазећи од методолошких позиција социолингвистике. Применом методологије социолингвистичке и лингвистичке анализе, а узимајући у обзир и теорију домена и друштвених мрежа, уз комбиновање квалитативног и квантитативног приступа у вредновању друштвених и лингвистичких интеракција, јасније се и лакше сагледава како скуп различитих фактора утиче на системсколингвистичке промене и промене са комуникацијског аспекта. Тако се детаљније могу објаснити процес замене/очувања језика и структурне промене у српском језику, пратећи у циклусима тог процеса припаднике најстарије (прве) генерације преко средње (друге) до најмлађе (треће) генерације. У истраживању смо заговарали интегрисани модел који представља покушај да се у обзир узму лингвистичке и друштвене варијабле у природним комуникацијским ситуацијама, односно укључивање изванјезичких фактора који утичу на лингвистичке варијације и начин реализације билингвалне компетенције. Спроведена анализа феномена језичких контаката има карактер студије случаја (case study) и представља емпиријско индуктивно истраживање на синхроној равни које смо обавили користећи се техникама социолингвистичког интервјуа са елементима непосредног посматрања.

\section{2. Ток истраживања}

Проучавање промена у српском језику и процеса замене српског немачким језиком у говорној заједници Срба у Инголштату захтевало је прикупљање грађе која се темељи на „живом“ говору припадника истраживане заједнице. У том емпиријском делу истраживања било је потребно изборити се са многим препрекама - од приступа испитаницима, преко финансијских потешкоћа до организације спровођења упитника и интервјуа. Многа истраживања оваквог типа уживају подршку државних институција или организација, како у погледу људских, тако и техничких и финансијских ресурса. Ми, нажалост, нисмо имали ни једно ни друго у правом смислу речи, те је у бити све било 
препуштено нашој сопственој иницијативи, сналажљивости и пре свега личној помоћи испитаника директно на терену.

Припремање за ово истраживање обухватало је више корака са доста испреплетаних етапа у којем се са аспекта структуре корака може пратити следећа нит:

Први корак се састојао у сазнавању важнијих фактора истраживане ситуације и трагању за (кључним) испитаницима ${ }^{3}$. Та фаза је била заступљена у етапама током свих осталих корака истраживања. У другом кораку смо на основу посматрања истраживане заједнице, као и на основу доступне литературе, саставили упитник ${ }^{4}$ Трећи корак, спровођење упитника, као и

3 Сам почетак истраживања везује се за 2010. годину, када смо успоставили прве контакте са трима кључним особама за даље контакте са Србима у Инголштату. Друге контакте са испитаницима смо остварили и путем фејсбук странице Српског културног удружења „Свети Сава“ као и путем класичног писаног обраћања Србима у Инголштату, чије смо адресе пронашли у телефонском именику на интернету.

4 Упитник за ово истраживање састављен је комбиновањем два већ постојећа упитника коришћена у сличним истраживањима (уп. Аубургер 1979: 100-120 и Ахтерберг 2005: 290-308). Упитник се састоји од шест комплекса питања којима су обухваћени: 1. социодемографски подаци (старост, пол, порекло, дужина боравка на немачком говорном подручју и сл.), 2. усвајање језика и језичка компетенција (примарна и секундарна социјализација, самопроцењивање језичке компетенције), 3. употреба немачког језика у Србији (у приватном, јавном и професионалном домену), 4. идентитет, 5. учесталост контакта са немачким језиком и 6. употреба језика у друштвеним мрежама испитаника. Међутим, током наших боравака, а посебно након повратка са последњег теренског истраживања и сагледавања прикупљене истраживачке грађе, схватили смо да је број испитаника обухваћенихупитником далеко мањи од броја испитаника обухваћених интервјуом. Ова несразмера није нам пружала добар основ за валидан методолошки приступ, те смо извесно време били у потрази за решењем насталог проблема. Размишљали смо да се ограничимо на само 28 испитаника обухваћених и упитником и интервјуом. Међутим, то би значило најпре бројчано сужавање испитаног узорка, а са друге стране, што нам се чинило и најважнијим, овакво би решење довело до неуједначене генерацијске заступљености испитаника. Тако смо се на крају ипак определили да анализу извршимо само са подацима добијеним на основу спроведених интервјуа. Грађа добијена овим упитницима је свакако веома драгоцена и може послужити за даље 
Јулијана Вулетић

први одвијао се паралелно у етапама са осталим фазама истраживања. Наредна, четврта фаза у истраживању била је спровођење интервјуа ${ }^{5}$ на основу тематских комплекса упитника, паралелно са непосредним посматрањем. Након овог корака уследио је пети корак, преслушавање интервјуа са транскрибовањем ${ }^{6}$. И као последњи, шести корак, уследила је обрада корпусне грађе, квалитативно и квантитативно вредновање лингвистичких и социолингвистичких података као и успостављање односа између социолингвистичких и лингвистичких података. Као закључак се намеће да се фазе рада не могу стриктно одвојити једне од других, већ да су се у одређеним периодима рада преплитале, при чему смо увек били наизменично у двострукој улози: у улози посматрача и улози учесника. При томе смо увек улагали напор да задржимо свест о томе, тј. да помиримо до извесне мере потребну неутралност и дистанцираност са субјективним посматрањем предмета истраживања.

Будући да би појединачни интервјуи одузели много времена како истраживачу тако и испитаницима, већини испитаника је одговарало да се интервјуи обављају породично у њиховим

анализе. Међутим, посматрано из данашње перспективе у контексту будућих истраживачких подухвата других аутора, сматрамо да би било ваљано да се комбинују технике социолингвистичких упитника и интервјуа, с тим што би било упутно да се постојећи, већ састављени упитник модификује у погледу односа питања, концентрације и одговора испитаника.

5 Интервјуима је обухваћено 27 породица (83 испитаника), а теренско истраживање обављено је у три етапе у периоду од јуна 2010. до октобра 2013. године. Наш корпус обухвата мигранте са простора некадашње Jyгославије који се декларишу као Срби, без обзира одакле да су потекли; сви информанти су штокавци екавског или ијекавског изговора.

6 Од укупно 53,5 сати снимљеног материјала 4 сата односи се на интервјуе вођене са децом, а сам транскрипт прикупљеногматеријала броји укупно 400 страна. У транскрипцији и приказу сегментираних примера говора испитаника којима смо илустровали анализиране појаве лексичких и граматичких трансференција и прекључивање кодова следили смо принцип ортографског правила литерарне транскрипције. Осим тога, поред говорних сегмената интервјуског типа током свог теренског истраживања забележили смо и примере комуникације испитаника у ситуацијама које нису биле интервјуског типа. 
домовима. Са децом ${ }^{7}$ су обављени посебни интервјуи у терминима одржавања радионице српског језика и вежбе фолклора. Током интервјуа смо питања искључиво постављали на српском језику и у самом разговору одговарали на српском, независно од тога на ком би нам се језику испитаници обратили. У неформалним разговорима и у непосредном посматрању ${ }^{8}$ карактеристичне појаве бележили смо по сећању.

Следећи комплексе питања ${ }^{9}$ са већ унапред дефинисаним областима и малим бројем структурираних питања уз коришћење форме неструктурираног/нестандардизованог и полуструктурираног/полустандардизованог интервјуа, дошли смо до података о социодемографским варијаблама (пол, вероисповест, брачно стање, степен образовања и сл.), о усвајању језика и употреби језика (хронологија усвајања језика, степен билингвалности испитаника, употреба језика у доменима и друштвеним мрежама у миграцији, матици и сл.), као и о $\mathrm{cma-}$ вовима у погледу очувања језика, идентита и културе. Интервјуи су вођени групно (од 2 до 5 учесника), у различитим окружењима и ситуацијама са елементима непосредног посматрања (породица, Српско културно удружење „Свети Сава“, кафић, рођендани, часови наставе српског језика, вежбе фолклора и сл.). Тиме смо желели да постигнемо што већи степен природности говора.

Интервјуима и непосредним посматрањем као комплементарним техникама успели смо да добијемо информације о

7 Радионицу српског језика похађало је 25 припадника треће генерације, од тога је на радионици затечено 23. Са децом предшколског узраста разговор је вођен у породичном окружењу. Према информацијама које смо у фебруару 2016. године добили од испитаника, ова радионица данас, на жалост, више не постоји. Ово ће бити један од битних фактора убрзане замене српског немачким језиком.

8 Током нашег боравка у Инголштату нисмо били у ситуацији да у потпуности применимо ову методу. Али на састанцима и дружењима, током и ван интервјуа, у неформалним ситуацијама које нису биле интервјуског типа, готово као члан колектива, били смо у прилици да стекнемо одређена запажања, лингвистичке и нелингвистичке податке о комуникативном и друштвеном понашању појединца или групе.

9 Питања су била формулисана у горе већ поменутом упитнику. 
социолингвистичким и лингвистичким репертоарима заједнице и њиховој међузависности, која се рефлектује у реализацији билингвалне компетенције у самом језичком систему и комуникацијском аспекту. У циљу лингвистичке анализе из говорног корпуса издвојили смо оне најтипичније језичке узорке ${ }^{10}$ како бисмо диференцирано илустровали релевантне појаве и процесе условљене непосредним контактом немачког и српског језика у дијаспоралним околностима, довели их у везу са друштвеним контекстом и оставили један документ о тренутном стању српског језика у немачкој дијаспори.

\section{3. Појмовна одређења}

Сазнања о међусобном утицају језика су постојала дуги низ векова, међутим, таквим феноменима није придаван посебан значај. Почеци модерних контактнолингвистичких истраживања се везују за Шухарта, који је препознао спрегу између двојезичности и мешања језика, тачније појаву међусобног утицаја језика у контакту. Прва систематска истраживања језичког контакта и вишејезичности активирана су средином педесетих година 20. века појавом дела Ј. Вајнрајха Језици уконтакту (Languages in Contact Findings and problems, 1953). Овим је делом Вајнрајх покренуо, усмерио, теоријски уобличио и терминолошки-појмовно опремио једну нову лингвистичку дисциплину под именом контактна лингвистика.

У контексту различитих приступа дефинисању контактне лингвистике и језичког контакта можемо закључити да су двојезичност и језички контакт међусобно тесно повезани. Језички контакт настаје посредном или непосредном социјалном интеракцијом говорника под утицајем комуникативног аспекта и социокултуролошког контекста. Језички контакти су пре резултат друштвених кретања него лингвистичких процеса. Ти друштвени процеси, уколико су интензивни, пред-

10 У наведеном раду је за потребе анализе издвојено 374 примера сегмената говора испитаника. 
стављају снажне спољне покретаче језичких промена. Имајући у виду психолингвистичко и социолингвистичко одређење појма контактне лингвистике, она представља једно вишедимензионално и интердисциплинарно поље истраживања.

У научној литератури, паралелно са хронолошком периодизацијом, у оптицају је и појмовна периодизација, у којој се смењују термини попут мешање језика, мешани језици, које хронолошки везујемо за предконтактнолингвистичко доба, а присутни су у првом периоду хронолошке периодизације. Ове термине смењује потом термин језичко, односно лингвистичко посуђивање. Од појаве Вајнрајхове монографије о језицима у контакту уводе се појмови језици у контакту, језички контакти, контактна лингвистика, лингвистика језичких додира, лингвистичка контактологија, заједно са појмовима интерференција, трансференција и прекључивање кодова, који обележавају и процесе и резултате језичког контакта. Појмови који су такође битни у контактној лингвистици јесу и билингвизам, матерњи језик и генерација, који се у зависности од типа језичког контакта различито тумаче и дефинишу.

У погледу разликовања и именовања појава, процеса и исхода језичког контакта, треба узети у обзир три дистинкције. То су 1) врста контакта (посредни/непосредни контакт); 2) утицаји међујезичког контакта на говор/систем према врсти контакта, тачније одражавању утицаја језика под контактом у равни синхроније и дијахроније и 3) утицаји језичког контакта у зависности од степена билингвалности. Као општи појам за све појаве индуковане језичким контактом користили смо термин феномени језичког контакта. А под феноменима језичког контакта даље подразумевамо: 1) двојезичност (вишејезичност) као последицу (настанак пиџина и креола), али и као узрок језичких утицаја; 2) трансференцију, која означава појаву преношења елемената, обележја и правила из једног у неки други језик, са својим последицама у синхронији/дијахронији у посредном/непосредном контакту са аспекта језичког система (настајање дијаспоралних језика, промене у стандардним језицима и сл.); и 3) прекључивање кодова и 4) замену језика са аспекта комуникације билингвалног говорника. 
Билингвизам у теорији контактне лингвистике заузима кључно место, будући да је, како услов, тако и последица језичких контаката. У складу са нашим истраживањем језичког контакта у миграционом контексту, ми смо се приклонили минималистичкој дефиницији билингвизма. Тако су билингвали и они испитаници који поседују само компетенцију разумевања. Следећи С. Липерт (2010) под рецептивним билингвалима подразумевамо говорнике који поседују способност да језик (делом) разумеју, али не и да говоре, а под пасивним билингвалима говорнике који поседују способност отежане и споре продукције на српском језику.

Као и М. Клајн $(1975,2003)$, ми потпуно избацујемо појам интерференција и одлучујемо се за појам трансференција као процес и трансфер као резултат. Трансференција своја полазишта има управо у контрастима између језика. Она је у различитим типовима језичког контакта у основи један те исти феномен, али који, у зависности од типа језичког контакта, изазива различите процесе и има другачије лингвистичке исходе. У научној литератури воде се, такође, многе дискусије о разликовању појава трансференције и прекључивања кодова. Ми смо у циљу свог истраживања извели два основна обележја разликовања ових појава. Тако сматрамо да за појаву трансференције постојање билингвалне заједнице, односно билингвалности говорника, није неизоставан предуслов, док то јесте за прекључивање кодова. Друго битно разликовање је што трансференција погађа системсколингвистичке равни језика, утиче на структуре језика под контактом и удаљава га од језика матице, док је прекључивање кодова комуникацијски условљен процес и не утиче на системске промене у језику А. Прекључивање кодова за последицу има краткорочну, тренутну замену језика А језиком Б у избору језика у комуникацијској ситуацији. Минимална јединица за трансференцију је лексема, а максимална фразеолексема у погледу лексичке трансференције, а на структурном нивоу су то граматичке релације и категорије.

Код прекључивања кодова минималном јединицом ове краткорочне замене језика сматрамо секвенцу реченице/ре- 
ченичног дела. У непосредном језичком контакту трансфер на једној страни може представљати окидач (triggering) за прекључивање кодова, а на другој за последицу може имати конвергенцију, тачније структурно изједначавање „слабијег“ језика А по узору на доминантни језик Б. Све ове појаве које прате непосредни језички контакт у миграционом контексту представљају фазе, односно стања које пролази језик мањинске заједнице у процесу замене језика. Језик мањинске заједнице у тим фазама, под утицајем наведених феномена непосредног језичког контакта, трпи промене како у свом лексикону, тако и у синтаксичким и морфолошким структурама.

Дефинисали смо такође и појмове говорна заједница, матерњи језик, дијаспорални језик и генерација. Под говорном заједницом у смислу заједнице говорника (linguistic community), тачније под ентнолингвистичком заједницом подразумевамо скупину више генерација српских миграната за које језик није увек оно што повезује све припаднике те заједнице. Матерњи језик у мигрантској ситуацији је такође комплексан проблем. Ми смо се определили за дефиницију Тове Скутнаб-Кангас, према којој мигрантско дете може имати више матерњих језика према критеријумима порекла, нивоа компетенције, функције и идентитета. Нашим испитаницима смо, при томе, дали слободу да сами одреде који је језик њихов матерњи језик. Терминима главни и споредни језик описујемо доминантност/ недоминантност једног језика у комуникацији испитаника у одређеним доменима и друштвеним мрежама. Српски језик испитаних билингвала ентнолингвистичке заједнице Срба у Инголштату, као и генерално у немачкој дијаспори, назван је српским дијаспоралним језиком, ${ }^{11}$ будући да је он као такав у процесу замене језика из немачког језика попримио лексику и

11 Дудок (2007: 239, 241) као и Ђурович дефинише језик дијаспоре као језик „хетерогеног карактера, јер су његови носиоци, појединци и чланови заједнице, расејани, далеко један од другог као и од матичног језгра [...]“, а дијаспору као „динамички, пулсирајући ентитет [...], као егзистенцијални тип мањинске популације која живи изван граница матичне земље са посебним и специфичним језичким обележјима у комуникацији“. 
структуре које га временом удаљавају од стандардног српског језика и његових територијалних варијетета у матици. И на крају, како су у контактнолингвистичком смислу српски радни мигранти и њихови потомци носиоци процеса замене језика и иницијатори промена у српском језику, било је неопходно дефинисати појам генеращије. Имајући у виду различите приступе одређењу овог појма под првом генерацијом радних мигранаma (миграната трећег таласа) подразумевају се мигранти који су шездесетих и седамдесетих година прошлог века дошли у Немачку ради запослења. Њихови потомци названи су другом генерацијом радних миграната, а потомци друге генерације трећом генерацијом радних миграната. Друга генерација радних миграната, у зависности од начина доласка у Немачку, подељена је на типове $1 \mathrm{a}, 16$ и 2 и ремигранте друге генерације ${ }^{12}$. У друштвеним мрежама испитаника затекли смо и припаднике савремене миграције или миграције четвртог таласа као и једну породицу, чије мигрантско порекло са прекидима датира још из периода првог таласа миграција. Њих смо, такође, обухватили истраживањем, будући да они представљају битан позитиван фактор у замени/очувању српског језика.

Процес замене језика као један од феномена језичког контакта представља прелазак појединца или групе са једне монолингвалности на другу монолингвалност. У оквиру социолингвистичког приступа процес замене језика и фактора, који у непосредном и дуготрајном језичком контакту утичу

12 Под припадницима друге генерације подразумевамо децу прве генерације и делимо их на три категорије: на децу која су доведена у Немачку, тј. другу генерацију типа 1a) и 16), децу која су у Немачкој рођена, тј. другу генерацију типа 2 и ремигранте друге генерације радних миграната. У другу генерацију типа 1a) сврставамо децу која су у земљу пријема доведена у току или након окончања примарне и почетка секундардне социјализације (до 12. године живота), у другу генерацију типа 1б) сврставамо децу која су у земљу пријема доведена у току или након завршетка секундарне социјализације (између 12. и 18. године живота). Ремигрантима друге генерације радних миграната сматрамо припаднике друге генерације који су у некој животној доби доведени у Немачку или су се у Немачкој родили, затим су у одређеном узрасту враћени у Србију, да би се касније поново вратили у Немачку. 
на процес замене/очувања језика, проучавају се у оквиру теорије домена, језичке екологије, теорије виталности и теорије друштвених мрежа. Ми смо у нашем истраживању процес замене језика пратили са аспекта утицаја домена и друштвених мрежа. У периоду трајања животног циклуса једне билингвалне заједнице, стање мањинског језика и понашање припадника говорне заједнице мањинског језика се мењају. Ове промене су условљене утицајем друштвених и језичких фактора. Из једне такве социолингвистичке ситуације у начелу произилазе фазе процеса замене мањинског језика већинским језиком, које могу обухватити више генерација. У литератури се континуум овог процеса приказује различитим фазним моделима, од којих нам се најпрецизнијим чини Винфордов петофазни модел; прву и пету фазу ми смо поделили на подфазе а) и б) ${ }^{13}$. Уз појединачне фазе процеса замене језика, разврстани су мигранти и у погледу генерацијске припадности, као и феномена језичког контакта који прате те фазе. Процес замене језика можемо тако дефинисати као „процес који почиње као монолингвалност неког типа и завршава се као нови тип монолингвалности након одређеног периода билингвалне фазе“14, односно као процес преласка са једне монолингвалности на билингвалност и

13 У фазу 1a сврставамо припаднике прве генерације и друге генерације типа 1б) и делом 1а) које карактерише монолингвалност и десоцијализација. За њом следи фаза 1б у којој се припадници наведених генерација одликују почетним билингвизмом и ресоцијализацијом. Језик Б се учи преко матерњег језика, али се употребљава у малом броју домена: у комуникацији унутар сопствене друштвене групе доминира матерњи језик са појавом лексичке трансференције без утицаја на граматички систем матерњег језика, док се нови језик користи у комуникацији ван сопствене друштвене групе, тачније у комуникацији са друштвом већинске заједнице и другим страним мигрантима. У фази $5 a$, етапи резидуалног билингвизма, остаје само друга генерација која као језик општења у комуникацији са трећом генерацијом користи језик Б, са драстичним редуковањем домена употребе језика А, и заједница постаје све више монолингвална на језику већинске друштвене заједнице. У фази 56 са постепеним одласком друге генерације и немогућношћу преношења језика А на наредно поколење нови језик потпуно преовладава у некада билингвалној заједници.

14 " [...] a process which starts with monlingualism of some type and concludes with a new type of monoligualism after a period of bilingualism [...]“ (Тандефелт 1992). 
Јулијана Вулетић

натраг ка другој монолингвалности, са фазама замене конфигурација доминантности у доменима употребе мањинског и већинског језика и пратећим манифестацијама језичког контакта у процесу замене језика.

\section{4. Резултати истраживања}

Полазећи од слободне процене испитаника да у Инголштату живи између 100 и 150 породица Срба, и од тога да су у истраживању учествовали чланови 27 породица, може се констатовати да смо нашим истраживањем обухватили $27 \%$, односно 18\% етнолигвистичке заједнице Срба у Инголштату. У раду смо користили термине истраживани корпус и испитани узорак. Истраживани корпус представља укупан број чланова породица (195); од укупног броја чланова истраживаних породица конкретним истраживањем обухваћено је 83 члана које смо назвали испитани узорак. Поређењем структуре истраживаног корпуса и испитаног узорка желели смо да прикажемо окружење у коме живи и функционише испитани узорак, те да одређени закључци до којих смо дошли могу да се као такви пренесу и на истраживани корпус. Дошли смо до резултата да је испитаним узорком обухваћено 43\% од укупног истраживаног корпуса. У даљој анализи смо показали да ова $43 \%$ испитаног корпуса одражава исте карактеристике по питању полне, а делимично по питању генерацијске, односно групацијске припадности. Варијабла пола показује идентичан однос у истраживаном корпусу и испитаном узорку (53\% : 47\% у корист женског пола). У погледу групацијске припадности у испитаном узорку губи се групација егзогама, а остају најбројније трећа и друга генерација радних миграната. Дакле, када упоредимо истраживани корпус са испитаним узорком видимо да једино веће квантитативно одступање постоји у групацији представника прве генерације радних миграната. Томе има више разлога: један део њих је у тренутку нашег истраживања боравио у Србији, један део није био заинтересован за истраживање, а неки живе ван Инголштата. 
У истраживаном корпусу, који чини 195 чланова истраживаних породица, заступљено је 37 монолингвала и 158 билингвала. Пошто смо утврдили да је 19\% истраживаног корпуса монолингвалан, а 81\% билингвалан, у даљој анализи смо дали приказ односа испитаних и неиспитаних билингвала, те дошли до резултата да наш испитани узорак чини 53\% укупног билингвалног корпуса.

Према варијабли хронологије усвајања језика у целокупном истраживаном билингвалном корпусу има 53\% раних консекутивних билингвала са прво усвајаним српским језиком, касних билингвала има $38 \%$ а рани симултани и рани консекутивни билингвали са прво усвајаним немачким језиком заступљени су са $5 \%$ и $4 \%$. Варијаблу хронологије усвајања језика смо потом приказали и према генерацијској, тј. групацијској припадности. Готово једнак процентуални однос у овој варијабли налазимо и у испитаном узорку. Добијени резултати потврђују нам да се српски језик преносио са прве генерације радних миграната на другу, као и да је друга, додуше у мањој мери услед више фактора, српски језик преносила на следећи нараштај, трећу генерацију радних миграната.

Процену варијабле степена билингвалности засновали смо на самопроцењивању наших испитаника и снимљеном језичком материјалу, те смо дошли до резултата да у нашем испитаном узорку преовлађује доминанта билингвалност у корист немачког језика са $51 \%$. Пасивни и рецептивни билингвали заступљени су са $13 \%$ и 6\% међу припадницима треће генерације радних миграната. Овај резултат нам говори да један део припадника друге генерације радних миграната истраживане заједнице, немоћан пред притиском сила друштвених мрежа, економских и друштвених односа у већинској друштвеној заједници, одустаје од преношења српског језика својој деци.

Однос резултата који смо добили у погледу одређења матерњег језика и употребе немачког и српског језика у породичном домену је несразмеран. Најразуђенију слику по питању матерњег језика нуди трећа генерација радних миграната. Од 31 испитаника ове генерације четрнаесторо њих изјављује да има два матерња језика; међу њима 9 испитаника даје пред- 
ност српском, а 5 немачком језику. Њих деветоро је изјавило да им је матерњи језик немачки, док је 8 испитаника рекло да им је матерњи језик српски. Њихово опредељење за српски као матерњи језик се, међутим, не поклапа са њиховом компетенцијом на српском језику нити са степеном употребе српског језика. Такви резултати говоре заправо о очувању националног идентитета припадника треће генерације миграната и степену њихове интеграције и асимилације у друштво већинске заједнице. Овакав став представника треће генерације радних миграната је у ствари углавном одраз става саме породице према вредностима као што су језик, култура и идентитет ${ }^{15}$.

Испитаници прве генерације радних миграната, друге генерације радних миграната типа 16 као и ремигранти друге генерације радних миграната - заједно са испитаницима прве генерације четвртог таласа и групације ендогама - дефинисани су као носиоци српског као матерњег језика понетог у миграцију. Српски језик истраживане етнолингвистичке заједнице, поред тога што је претрпео лексичке и структуралне промене под утицајем немачког, показује и варијететне различитости попут територијалне (Србија, Босна, Хрватска) и социјалне (колоквијална и обележја карактеристична за одређени степен образовања наведених групација). Таква обележја су се преносила и преносе на другу и трећу генерацију радних миграната. Ове карактеристике српског језика испитаника илустроване су типичним примерима (,по дваес, триес километара; ,раде са Њемцима; ,шта ти тражиш овде код наше комшике'; ,моја мама је исто из Србију' итд.).

Испитаници друге генерације радних миграната типа 2 и типа $1 \mathrm{a}$, друге генерације миграната четвртог таласа, пете и

15 Али, не треба генерализовати. Тако у нашем истраживаном корпусу у породицама Пш (испитаница Пшб, друга генерација радних миграната другог типа) и Ан (представници друге генерације типа 16 и типа 2) и представници треће генерације и поред негативног става родитеља према очувању српског језика желе да науче српски језик. Међутим, главни проблем јесте овде недостатак одговарајућих друштвених мрежа у којима би се развијале њихове компетенције на српском језику. Тако је испитаница Пшми пасивни билингвал, док су у породици Ан представници треће генерације миграната монолингвали на немачком језику. 
четврте генерације миграната првог таласа и треће генерације радних миграната су оне генерације које су српски језик усвајале ван матичне земље, у Немачкој. Ове генерације се сматрају кључним иницијаторима промена у српском језику и замене/очувања српског језика у миграцији.

\section{1. Социолингвистичка анализа}

У социолингвистичкој анализи издвојиле су се међу генерацијама радних миграната кључне разлике које су битне за правац језичког развоја српске етнолингвистичке заједнице у Инголштату, али и у српској дијаспори у Западној Европи. Између испитаника прве и друге генерације радних миграната констатовали смо четири битне социолингвистичке разлике:

$\rightarrow$ начин усвајања немачког језика;

$\rightarrow$ неукљученост/укљученост у друштво већинске заједнице;

$\rightarrow$ став према трајном/привременом боравку у Немачкој и

$\rightarrow$ став према српском језику.

Друга генерација радних миграната је немачки језик усвајала са интегративном мотивацијом, те је за разлику од прве генерације радних миграната, без обзира на сегрегираност и једне и друге, бивала више укључена у друштвене токове већинске заједнице. За разлику од друге генерације радних миграната, прва генерација није донела јасну одлуку о томе да ли је њен боравак у Немачкој трајан или привремен; ипак, друштвене околности (политика земље пријема и политика земље порекла) говориле су у прилог томе да је реч о привременом боравку. Тако је друга генерација радних миграната кроз југословенске допунске школе заправо била припремана на реинтеграцију у домовини. Самим тим, прва генерација миграната имала је јасан став о преношењу матерњег језика на другу генерацију. Она и дан-данас инсистира на употреби српског језика у породичном домену. Испитаници друге генерације, за разлику од прве, донели су јасну одлуку и имају јасну представу о томе да је Немачка земља њиховог трајног боравка.

У односу на разлике у социолингвистичким факторима између испитаника друге и треће генерације издвојиле су се две значајне разлике: 
$\rightarrow$ начин усвајања српског језика и

$\rightarrow$ однос и контакти са матичном земљом.

Док су испитаници друге генерације миграната типа 1a и 2 српски језик у миграцији усвајали као први језик у породичном домену и поред тога били све до постојања СФРЈ у обавези да похађају југословенску допунску школу, дотле трећа генерација радних миграната одраста у потпуно другачијим друштвеним околностима. Деведесетих година 20. века мењају се политичке околности у некадашњој матичној држави Југославији - укидају се југословенске школе, гасе се југословенски клубови, економско стање у матици се погоршава. Услед ових друштвених кретања друга генерација радних миграната одлучује се за трајни боравак у Немачкој. Тиме се код многих јавља питање да ли српски језик уопште да преносе својој деци. Ова промена друштвених околности и личног става друге генерације радних миграната одражава се како на хронологију усвајања језика тако и на степен билингвалности припадника треће генерације радних миграната. Друга генерација радних миграната је осим тога, за разлику од треће, имала густе сегрегиране друштвене мреже у приватном и пословном домену - становање, слободно време (југословенски клубови), југословенска школа - и интензивније контакте са матицом. Код треће генерације ови домени и друштвене мреже или више не постоје или су веома ослабљени.

Дакле, српски језик, тачније његови варијетети које су Срби с краја шездесетих година прошлога века понели са собом доселивши се у Немачку, постоји сада у једном сасвим другачијем социокултуролошком оквиру, губи стабилност, трпи промене под утицајем већинског језика и престаје да остварује сврху у друштвеном контексту. Овај однос снага српског и немачког језика огледа се и у његовој употреби, посебно у интрагенерацијској и интергенерацијској комуникацији испитаника. До важних закључака у овом смислу дошли смо најпре непосредним посматрањем. Испитаници прве генерације радних миграната су у интрагенерацијској комуникацији, као и у комуникацији са истраживачем користили искључиво српски 
језик. Исти начин комуникације карактерише интергенерацијску комуникацију прве, друге генерације радних миграната, ремиграната друге генерације, прве генерације четвртог таласа и четврте генерације миграната првог таласа и ендогама. Интрагенерацијску комуникацију друге генерације радних миграната одликује употреба српског језика као главног, а немачког као споредног језика. У интергенерацијској комуникацији свих горе наведених генерација са трећом генерацијом радних миграната, другом генерацијом миграната четвртог таласа и петом генерацијом миграната првог таласа употреба српског и немачког варира од породице до породице. У неким породицама се родитељи доследно придржавају подељених језичких улога, у неким породицама се родитељи обраћају деци на српском, а деца одговарају на немачком. Нека деца строго раздвајају језике, те када им се неко обрати на српском, одговарају на српском, и обрнуто. У оваквој интергенерацијској комуникацији може се, такође, запазити да се због тежег разумевања и споре продукције на српском код треће генерације радних миграната у свакодневном животу користи немачки језик како би се неки посао или задатак брже обавио.

Трећа генерација радних миграната, друга генерација миграната четвртог таласа и пета генерација миграната првог таласа у својој интрагенерацијској комуникацији користе искључиво немачки језик. Приликом породичних интервјуа, на пробама фолклора и часовима српског језика може се, међутим, приметити да деца међусобно разговарају и на српском и на немачком језику са честим прекључивањем кодова.

Посматрањем комуникације испитаника са истраживачем и у међусобној комуникацији испитаника током интервјуа дошло се до занимљивих констатација. Неки испитаници су у разговору са истраживачем водили рачуна о томе да користе што коректнији српски језик са што мање трансферисаних лексема, али су у комуникацији са припадником своје породице користили српски језик са адаптираним/неасимилованим лексемама и/или прекључивањем кодова. У комуникацији са истраживачем су поједини испитаници улагали доста напора да задрже континуитет разговора на српском, па је је њихов 
говор био пропраћен конверзационим карактеристикама попут уздаха, пауза, колебања у говору. Такође, често је долазило је до блокирања лексичких/граматичких трансференција и прекључивања кодова, негде са појавом неутрализације, тачније узастопног понављања речи или исказа и на српском и на немачком језику.

\section{2. Лингвистичка анализа}

Анализирани корпус говорног дискурса 83 испитаника чини 53,5 сати снимљеног говора са транскриптом од 400 страна. У то спадају како интервјуи, тако и говор забележен непосредним посматрањем. Феномени језичког контакта који се јављају у говору испитаних српских миграната илустровани су уз помоћ 374 примера сегментираног говора испитаника на основу транскрипта и бележака насталих непосредним посматрањем. Анализом лексичких трансференција у говору испитаника наметнуо се закључак да је појава лексичке трансференције присутна код свих испитаних групација, али да између њих постоје у том погледу квантитативне и квалитативне разлике. Адаптирани трансфери забележени су у говорном дискурсу прве и друге генерације радних миграната (са свим подтиповима), прве генерације миграната четвртог таласа и ендогама, али не и код треће генерације радних миграната, друге генерације четвртог таласа, четврте и пете генерације миграната првог таласа. Ипак, овај феномен језичког контакта најзаступљенији је у говору прве генерације радних миграната $^{16}$. Реч је о трансференцији свих врста речи, о лексемама из свих сфера живота, а највише о реалијама које су везане за културу, администрацију и уопште за целокупно друштво земље

16 Оно што је карактеристично пре свега за припаднике испитног узорка који спадају у касне билингвале јесте да испитаници асимиловане трансфере именица и глагола прилагођавају језичком систему српског језика, нпр. 'на бауштели, ауфнемати, бештеловати' и сл., или пак одређеним граматичким категоријама свог локалног говора који су понели у миграцију. Тако смо у говору испитаника Ан забележили пример 'ишли смо аутобанем', са падежном морфемом карактеристичном за локарни говор у околини Крушевца. 
пријема ${ }^{17}$. Те лексеме постале су делом лексикона српског језика ове генерације а и других генерацијских групација.

Код друге генерације радних миграната (са свим подтиповима) приметна је употреба како адаптираних, тако и неасимилованих лексичких трансфера. Ова појава се може објаснити тиме што су адаптиране лексеме као такве већ ушле у лексикон српског дијаспоралног језика, док неасимиловане служе за затварање тренутних празнина у индивидуалном лексикону. У говору групације ендогама и представника прве генерације миграната четвртог таласа присутни су углавном адаптирани трансфери. Заједничко овим испитаним групацијама је то што је лексичка трансференција углавном ограничена на именице и глаголе, при чему код друге генерације радних миграната предњаче неасимиловане именице.

У говорном корпусу треће генерације радних миграната и друге генерације миграната четвртог таласа није забележен велики број примера лексичке трансференције, а они коју су идентификовани јесу пре свега неасимиловани трансфери којима припадници ових генерација затварају лексичке празнине у индивидуалном лексикону.

Калкирање немачких фразеолексема у српски језик највише је заступљено код прве и друге генерације радних миграната (са свим подтиповима), ендогама и прве генерације миграната четвртог таласа. Неке од ових трансфера бележимо у говорном дискурсу свих испитаних групација, те на основу тога можемо да закључимо да су овакви трансфери ушли у лексикон српског језика у миграцији ${ }^{18}$. Примери за трансфер немачких творбених образаца нису забележени (сем 'груповођа', 'расисткиња' и 'националисткиња'19), али је приметно да

17 Попут 'културамт', 'ауслендерамт', 'културреферат', 'финанцамт', 'биргерфест', 'ратхаус', 'бауамт', 'лигеншафт'/'лигеншафтсамт', 'мервертштојер', 'кранкенкасе', 'конто', 'арбајтсамт', 'пфингстен', 'реалшуле', 'хауптшуле', 'аусбилдунг', 'штау', 'пасати'.

18 Нпр. ја сам <=матуру направила> према 'Abitur machen';<=направи ми термин>; према 'einen Termin machen'; <=ушли са њима у контакт>' према 'mit jemandem in Kontakt treten' и сл.

19 Ова тенденција се може уочити и у оквиру развојних процеса у српском језику, тачније пре као резултат јавног лингвистичког дискурса него иманентно језичких процеса. Сматрамо да испитаницима нису познати ови процеси у српском језику. 
се за немачке детерминативне сложенице као кореспондентни употребљавају преведенице (у виду номиналне фразе, понегде и са погрешним семантичким трансфером) ${ }^{20}$.

Такође, код свих испитаних групација, осим код испитаника треће генерације миграната и друге генерације миграната четвртог таласа, карактеристично је да степен лексичког трансферисања зависи од комуникацијске ситуације, односно саговорника, те је у разговору са истраживачем уопштено гледано приметан нижи степен лексичке трансференције.

Без обзира на ове разлике квалитативног и квантитативног типа, у анализи лексичких трансференција су идентификовани лексички трансфери који су заједнички свим испитаним генерацијама и групацијама. То доводи до закључка да су они већ постали делом лексикона српског дијаспоралног језика испитаника ${ }^{21}$.

Што се тиче граматичких трансференција на плану синтаксе и морфологије, спроведена анализа је показала да је у говорном корпусу прве генерације радних миграната, прве и друге генерације миграната четвртог таласа, четврте и пете генерације миграната првог таласа као и ендогама овај феномен језичког контакта најмање заступљен. Међутим, за ове испитане групације је карактеристично да се граматички трансфери јављају готово у свим сегментима граматичког система, као и код припадника других испитаних групација код којих је та појава само интензивнија. Највећи број структура страних српској језичној норми, а које су резултат транференције граматичких правила немачког језика, приметан је у говору

20 Нпр: 'Tagesmutter' као 'дневна мама'; 'Geburtstagskind' као 'рођенданско дете'; 'Holzofen' у виду номиналне фразе 'дрвена пећ' уместо 'пећ на дрва' и сл.

21 На пример, погрешан семантички трансфер глагола 'sprechen' у фразеолексеми *'причати неки језик' бележимо у говору свих испитаних групација, док погрешан семантички трансфер глагола 'können' и 'spielen' бележимо код треће генерације радних миграната у фразеолексемама *'моћи неки језик' и *'играти неки инструмент'. Именицу 'интерес' у фразеолексеми 'имати интерес' са погрешним семантичким обележјем у значењу 'интересовање' забележили смо код свих испитаних групација, сем у говору деце. Именице 'Pause', 'Sport' (пауза, спорт) су са погрешним семантичким обележјем унете из домена школе у породични домен; оне су постале делом лексикона свих испитаних групација. 
представника друге и треће генерације радних миграната и код ремиграната друге генерације.

Утицај немачког језика на синтаксичком нивоу огледа се у трансферу валентности глагола, ређе именица и придева, реченичној и посебној негацији, истицању личне заменице у функцији субјекта, а највише у транферу реда речи у реченици. Трансференција валентности глагола (и именица) присутна је највише код представника треће и друге генерације радних миграната, при чему се прегледом ексцерпираних примера може констатовати да су примери за валентност глагола бројнији ${ }^{22}$. Услед трансференције граматичке категорије рода именица из немачког у српски језик долази до појаве погрешне конгруенције детерминатива и придева са именицама у роду, броју и падежу у именичким фразама и конгруенције у реченици која се своди на слагање именица или заменица у функцији субјекта са личним и неличним глаголским облицима (радни придев). ${ }^{23}$ Највећи број примера за појаву овог типа граматичке трансференције ексцерпиран је из говорног корпуса треће генерације радних миграната. Ова појава присутна је у мањој мери и у говору друге генерације радних миграната, као и ремиграната друге генерације.

У вези са конгруенцијом и трансфером граматичког рода немачких адаптираних именица код прве генерације радних миграната забележена је појава трансфера рода немачке именице или сврставање адаптиране именице у именичку парадигму српског језика. Највећи број примера за трансференцију правила употребе реченичне и посебне негације по моделу немачког језика забележен је такође у говору треће генерације радних миграната. ${ }^{24}$ Појава истицања субјекта по угледу на правила немачког језичког система идентификована је у говору свих испитаних групација, али је ова појава опет била

22 Нпр.: 'нисам био у фејсбук'; 'знам, ради се од једну жену'; 'жена из Тајланда' итд.

23 Нпр.: 'из моје разред'; 'петком имамо исто физичко, а то је трећа и четврта |// четврти час'; ' 'ишли аутобанем'; 'испала машина 74 евра са мервертштојера'; 'да би школе знали'.

24 Нпр: 'прво сам ништа нашла'; 'кад ја еве на српски кажем'. 
најчешће заступљена у говору треће генерације радних миграната. У погледу степена заступљености трансференције реда речи из немачког језика у српски, предњаче представници треће и друге генерације радних миграната, а следе их ремигранти друге генерације. Ова појава се огледа у погрешном месту глаголских и заменичких енклитика у реченици, затим у трансференцији позиције елемената (управни глагол, помоћни глагол, допуне итд.), у употреби простих и сложених глаголских облика, како у зависним тако и независним реченицама ${ }^{25}$.

На морфолошком плану српски језик треће генерације радних миграната највише показује одступања у погледу редукције падежног система, док је погрешна употреба несвршеног уместо свршеног глаголског вида, као и употреба детерминатива 'ein', и неодређених заменица 'eine/r/s', највише заступљена у говору друге и треће генерације радних миграната $^{26}$. У погледу рефлексивности глагола као и погрешног трансфера повратних заменица под утицајем немачког језика забележени су примери у говору прве и друге генерације радних миграната и ендогама, а коришћење пасивних наместо активних конструкција по угледу на немачки језик било је заступљено са неколико примера у говорном корпусу ендогама и прве генерације радних миграната ${ }^{27}$. Ова појава није била присутна у говору других генерација.

Уопштено гледано процес „структурног уједначавања“ српског по угледу на немачки, тачније повећање заједничких структурних карактеристика српског са немачким језиком прогресивно расте од прве ка трећој генерацији, мада се овај закључак не може генерализовати. ${ }^{28}$

25 Нпр.: 'аха, ти преконтролишеш га'; 'ја овде долазим зато што Јасна је супер учитељица'; 'кад ⿺ јо јој кажем'; 'кад сам била мала сам те коње добила од бабе' и сл.

26 Нпр: јер ако једна неће, она неће'; ] ајд` иди ти, па каже само још један (--) |/| неко да ми каже да хоће неку животињу'.

27 Нпр: 'нисам доживео тако нешто где морам да мене контролирам'; 'ја [већ две, три вечери] истуширам ме'; ' 'и на једно место сам се само, како се каже, конкурисао' ; 'негде сам попреко погледана'; итд.

28 Тако, на пример, у говору испитаника К међу представницима прве генерације радних миграната имамо најизразитију појаву конвергенције. 
У погледу прекључивања кодова, дакле, комуникацијског аспекта испитане билингвалне заједнице, анализа је показала да појава овог феномена и његов степен најпре зависи од саговорника и теме, става саговорника према српском језику. Отуда већина наведених примера потиче из комуникацијских ситуација које нису биле интервјуског типа, већ су добијени непосредним посматрањем током породичних интервјуа приликом интергенерацијске или интрагенерацијске комуникације. На основу приказане анализе може се закључити да је прва генерација радних миграната најмање подложна појави прекључивања кодова. Можемо рећи да је ова генерација још увек бедем очувања српског језика у дијаспори, будући да инсистира на употреби српског језика у породичном домену. У међусобној комуникацији друге генерације радних миграната, ремиграната друге генерације и ендогама прекључивање кодова, такође, забележено је само у смислу цитирања туђих или својих речи. Током вођених интервјуа, али не и у разговору са истраживачем, фиксирана је појава прекључивања кодова у комуникацији између друге и треће генерације радних миграната. До тога је долазило пре свега услед тренутне или перманентне празнине у индивидуалном лексикону говорника која је најпре проузроковала појаву лексичке трансференције у виду асимиловане/ неасимиловане лексеме. У језичкој пракси испитаника, посебно у комуникацији прве и друге генерације са трећом, до преласка на другу монолингвалност долази зато што је услед слабљења или недовољне компетенције треће генерације на српском језику комуникација на немачком бржа и лакша.

\section{3. Замена језика - тренутно стање}

Наша истраживана етнолингвистичка заједница се данас, према социолингвистичким и лингвистичким показатељима добијеним спроведеном анализом, налази у 3. фази процеса замене језика. У испитаном узорку српски језик као главни језик општења заступљен је у 9 породица, у 5 породица српски полако губи примат, у 2 породице су и српски и немачки подјед- 
нако заступљени, док је у 13 породица немачки главни језик комуникације у породици. Од укупног броја породица у 7 породица је већ дошло до замене језика. Према процени на основу сазнања о ставовима, језичком понашању и употреби, српски језик има будућност да опстане као споредни језик општења у 17 испитаних породица. Код ових 17 породица се и друштвене мреже приватног домена састоје од јаких, слабих и пасивних веза у матици и миграцији, прате се медији на српском језику, а десет породица активно учествује у раду Удружења.

У погледу процеса замене/очувања српског језика у немачкој дијаспори, тачније у нашем истраживаном корпусу и испитаном узорку, издвојили су се следећи битни фактори:

$\rightarrow$ генерацијска припадност, која повлачи за собом:

$\rightarrow$ начин учења језика,

$\rightarrow$ начин обављања секундарне социјализације,

$\rightarrow$ степен образовања,

$\rightarrow$ контакте са матицом,

$\rightarrow$ полну припадност (склапање ендогамних/егзогамних бракова $\left.{ }^{29}\right)$,

$\rightarrow$ друштвени успех у земљи пријема,

$\rightarrow$ став родитеља према матерњем језику,

$\rightarrow$ институционалну подршку.

Религија и црква као фактори у процесу замене језика у истраживаном корпусу немају готово никакву улогу у погледу очувања језика и представљају неискоришћен домен за очување српског језика у српској заједници у Инголштату. Исто тако, пресудан утицај за очување језика не представљају чак ни позитиван став родитеља према српском језику, као ни ре-

29 Ендогамне браковеунашем истраживањуделимонадватипа.Подпрвим типом подразумевамо брак између припадника миграната у Немачкој са Српкињом/Србином из Србије, нпр. као код испитаника породице А и Д. Други тип ендогамног брака је брак између представника исте генерације миграната. То је, рецимо, случај код породице Ђ, где су оба брачна партнера припадници друге генерације миграната другог типа. У првој ситуацији је вероватноћа да језик општења у породици буде српски већа него код другог типа ендогамних бракова за шта смо потврду зо ову претпоставку нашли у испитаном узроку. 
лативно велика бројчаност говорника српске заједнице, већ изградња хомогених локалних друштвених мрежа за његову употребу. Позитивни фактори за очување језика у истраживаном корпусу који могу на кратко да зауставе процес замене језика јесу постојање прве генерације радних миграната која у породичном домену инсистира на употреби српског језика, друштвене мреже око Српског културног удружења „Свети Сава“, са активностима у виду фолклора и радионице српског језика, затим ендогамни бракови другог типа, као и постојање друштвених мрежа прве генерације миграната четвртог таласа и најновијих миграција које су у јеку.

Према нашем мишљењу, судбина српског језика у миграцији данас је у рукама треће генерације радних миграната. Да ли ће ова генерација бити у стању да српски (дијаспорални) језик даље преноси зависиће од сплета друштвених и личних околности. Будући да сам процес очувања српског језика у дијаспори изискује огромна улагања енергије, труда и финансијских средстава, он остаје изван домашаја могућности појединаца и саме дијаспоре. Стога је потребно да постоји организована, тесна, интензивна и централизована међусобна сарадња надлежних српских институција попут Министарства просвете и Министарства за дијаспору ${ }^{30}$, организација и удружења Срба у Немачкој, немачких надлежних институција као и научних институција једне и друге земље. Њиховим заједничким залагањем биће могуће изградити претходно поменуте хомогене друштвене мреже ${ }^{31}$. Ту мислимо на интензивнију и организованију допунску наставу српског језика са модерним наставним средствима и савременим наставним и ваннаставним програмима, који ће привући пре свега трећу генерацију миграната, затим формирање (дечјих) библиотека, склапање партнерстава

30 На пример, Министарство за дијаспору је 2012. године покренуло пројекат „Сваки Србин зна српски“, али поменути пројекат уопште није био познат српској заједници у Инголштату.

31 У ове друштвене мреже били би укључени и представници савремених миграција који би представљали моћан механизам за очување српског језика, што ће неизоставно утицати и на језичко понашање миграната претходних таласа миграција. 
основних и средњих школа у Србији са српским удружењима у Немачкој и размена ученика и сл. Тиме би био отворен пут ка важном позитивном фактору очувања језика, тачније интезивнијем и директнијем контакту са матицом и стварању ефекта непрекидних друштвених мрежа у самој матици. Оне ће пружити тај неопходни друштвени оквир који ће се одразити и на личне животне околности треће генерације радних миграната (нпр. већи степен повезаности са српском заједницом у Немачкој као и у матици, позитиван став према српском језику и његовој употреби, склапање ендогамних бракова и сл.).

Надамо се да смо својим радом дали мали допринос почецима истраживања српског дијаспоралног језика, која са једне стране могу допринети, како теорији контактне лингвистике и језичког контакта, тако и емпирији и практичном коришћењу резултата истраживања (језичка политика, наставна средства за трећу генерацију радних миграната и сл).

\section{Закључак}

На основу изнетих резултата свеукупне анализе процеса замене српског језика немачким на конкретном корпусу општи закључак који се може извући гласи да се испитана заједница Срба у Инголштату према лингвистичким и социолингвистичким показатељима налази у 3. фази процеса замене језика.

У овој фази се прва генерација радних миграната повлачи и постепено нестаје, а однос снага језика у интергенерацијској и интрагенерацијској комуникацији је промењен, тачније немачки језик постаје главни језик општења. Док је језик интрагенерацијске комуникације прве генерације радних миграната и интергенерацијске комуникације прве и друге генерације радних миграната искључиво српски ${ }^{32}$, дотле у интрагенерацијској комуникацији друге генерације радних миграната

32 Њу прати обиље адаптираних лексичких трансференција и ретке граматичке трансференције као и ретко прекључивање кодова код прве, а код друге интензивније неасимиловане лексичке као и граматичке трансференције, са прекључивањем кодова. 
почиње уопштено гледано да преовладава немачки језик ${ }^{33}$. У комуникацији између прве/друге генерације са трећом генерацијом радних миграната доминира немачки језик ${ }^{34}$ са честим прекључивањем кодова, лексичким и граматичким трансференцијама које су већ обележје новог, дијаспоралног језика. Трећа генерација радних миграната сада српски језик усваја углавном преко немачког језика и усваја га у знатно промењеном облику од језика са којим је прва генерација радних миграната отишла у миграцију. Степен присутности одређених трансференција сведочи о томе да се језик прве генерације радних миграната, ендогама, прве генерације миграната четвртог таласа немачком језику највише приближио на лексичком плану, док је језик друге, а првенствено треће генерације, умногоме попримио структурална обележја немачког језика.

За разлику од Филиповића $(1986,1984)$ и других који трећу генерацију сматрају оном у којој је наступила замена језика ${ }^{35}$, код нас ова генерација, са пратећим индивидуалним утицајима, представља пресудан, боље рећи амбивалентан фактор у погледу очувања/замене језика. Како је сада позиција треће генерације радних миграната као и став немачког друштва у погледу интеграције миграната слична условима у којима се налазе исељеници у прекоокеанским земљама, природан резултат хијерархијских друштвених, економских и других односа који владају између етнолингвистичких заједница и већинског друштва јесте убрзана замена језика ${ }^{36}$. Овај убр-

33 Овакву комуникацију прате неасимиловани трансфери, прекључивање кодова и појачана граматичка трансференција.

34 Нпр. родитељ/деда и баба се детету/унуку обраћају на српском језику, а дете/унук одговара на немачком.

35 Ово је разумљива констатација, будући да је Филиповић истраживао језик прекоокеанских исељеника са социолингвистичким факторима знатно другачијим од фактора који су присутни у западноевропској миграцији, а који утичу на брзо урушавање билингвалне заједнице.

36 Затварањем два важна домена у друштвеним мрежама испитаника која су постојала до скора, радионице српског језика и фолклорне секције, процес замене језика, тачније прелазак са фазе билингвалности у фазу монолингвалности на немачком језику, попримиће према свим претпоставкама веома убрзан ток. 
зани процес замене језика може се предупредити одређеним мерама од стране институција матичне државе Србије којима ће се даље створити услови за очување језика и националног идентитета у наредним нараштајима српске миграције.

И на крају, полазећи од личног искуства, указали бисмо у овоме закључку и на потребу организованог, институционализованог и интердисциплинарног приступа овој теми, а пре свега на неопходну сарадњу са србистима са простора Балкана.

\section{ЛИТЕРАТУРА}

Аубургер 1979: Auburger,L. Deutsche Sprachkontakte in Übersee: nebst einem Beitrag zur Theorie der Sprachkontaktforschung. Tübingen: Narr. Ахтерберг 2005: Achterberg, J. Zur Vitalität slavischer Idiome in Deutschland:eine empirische Studie zum Sprachverhalten slavophoner Immigranten. München: O. Sagner.

Винфорд 2003: Donald, W. An introduction to contact linguistics. Blackwell Publishing.

Дудок 2007: Dudok, M. Od jezika dijaspore ka preventivnoj lingvistici?, Зборник Матище српске за филологију и лингвистику, 50, 1-2, 239-250.

Ивановић 2012: Ivanović, V. Geburtstag pišeš normalno: Jugoslovenski gastarbajteri u Austriji i SRN 1965-1973. Beograd: Institut za savremenu istoriju.

Клајн 1975: C.Michael, Forschungsbericht Sprachkontakt. Untersuchungsergebnisse und praktische Probleme. Kronberg/Taunus: Script Verlag.

Клајн 2003: C. Michael, Dynamics of language contact: English and immigrant languages. Cambridge, New York: Cambridge University Press.

Липерт 2010: Lippert, S. Sprachumstellung in bilingualen Familien. Zur Dynamik sprachlicher Assimilation bei italienisch-deutschen Familien in Italien, Waxmann, Waxmann Münster/New York/München/Berlin.

Павлица 2005: Pavlica, B. Migracije iz Jugoslavije u Nemačku - migranti, emigranti, izbeglice, azilanti, www.doiserbia.nb.rs/ft.aspx?id=002585550502121P, pregledano 15.11.2016.

Тандефелт 1992: Tandefelt, M. Some linguistic consequences of the shift from Swedish to Finnish in Finland. In Willem Fase, Koen Jaspaert, \& Sjaak Kroon (eds.), Maintenance and loss of minority languages, 149-168. Amsterdam: John Benjamins. 
Филиповић1984-1985: Filipović, R. (1984-1985). Odnos posrednog i neposrednog posuđivanja u teoriji kontaktne lingvistike, Зборник Матище српске за филологију и лингвистику, XXVII-XXVIII, 861-867. Филиповић 1986: Filipović, R. Teorija jezika u kontaktu: uvod ulingvistiku jezičnih dodira. Zagreb: Jugoslovenska akademija znanosti iumjetnosti, Školska knjiga.

\section{Julijana Vuletić}

\section{PROZESS DES SPRACHWECHELS DER SERBISCHEN DURCH DIE DEUTSCHE SPRACHE - EINE STUDIE}

\section{Zusammenfassung}

Das Ziel und die Aufgabe dieses Beitrags war es, die Ergebnisse der dreijährigen Untersuchung und Analyse des Sprachwechselprozesses in der serbischen Gemeinschaft in Ingolstadt, Bayern mit kurzem Rückblick auf den Untersuchungsablauf und Begriffsbestimmungen darzustellen.

Schlüsselwörter: Sprachkontaktforschung, Sprachwechselprozess, Phänomene des Sprachkontaktes

Примљено 1. септембра 2016. године Прихваћено за објављивање 10. новембра 2016. године 